\title{
LEVEL AND EVOLUTION OF FARM TAXATION IN THE EUROPEAN UNION IN 2007-2015
}

\author{
Joanna Średzińska, $\mathrm{PhD}^{1}$; Agnieszka Kozera, $\mathrm{PhD}^{2}$; Aldona Standar, $\mathrm{PhD}^{3}$
}

Faculty of Economics and Social Sciences, Poznań University of Life Sciences

\begin{abstract}
The purpose of this paper is to assess the level of and changes in taxes imposed on farms in European Union countries. The empirical study was based on FADN data. Because of the complex nature of aspects under consideration, the TOPSIS method was used to develop a synthetic indicator of farm taxation. The study was carried out in 2007-2009 and 2013-2015. For these periods, average values of simple characteristics were calculated which reflect the levels of farm taxation and are the basis for the synthetic indicator. Afterwards, the synthetic indicator was used to linearly arrange the countries by farm taxation levels in the EU in the periods considered.
\end{abstract}

Keywords: taxes, farms, European Union, FADN, TOPSIS

JEL codes: H21, Q14, Q18

\section{INTRODUCTION}

Agriculture is an important part of the economy of most European Union countries, and is subject to taxation just like any other sector. Contrary to common belief, numerous taxes are imposed on farming activities, including: agricultural tax, property tax, forestry tax, vehicle tax and VAT (Golasa, 2015). Agricultural taxation is of major importance for the competitiveness of economic operators active in the agriculture sector. The agricultural taxation policies in place differ from one EU country to another. The solutions adopted for the agricultural taxation model may support the farming activities, be neutral or hamper the development of specific economic sectors (Wasilewski and Ganc, 2012; Kulawik et al., 2013).

The main purpose of this paper is to assess the level of and changes in farm taxation in the European Union. The level of EU farm taxation was analysed based on 2007-2009 and 2013-2015 FADN $^{5}$ data.

\section{THEORETICAL BACKGROUND}

The national farming taxation policy includes defining tax rates and tax bases, and granting tax preferences and relieves (for a broader description, see Kulawik

${ }^{1}$ Corresponding author: Wojska Polskiego 28,60-637 Poznań, Poland, sredzinska@up.poznan.pl, +4861 8466376

${ }^{2}$ Corresponding author: Wojska Polskiego 28, 60-637 Poznań, Poland, akozera@up.poznan.pl, +4861 8487111

${ }^{3}$ Corresponding author: Wojska Polskiego 28, 60-637 Poznań, Poland, standar@up.poznan.pl, +4861 8466376

${ }^{4}$ The empirical study was based on average figures from 2007-2009 and 2013-2015.

${ }^{5}$ Farm Accountancy Data Network webpage http://ec.europa.eu/agriculture/rica/database/database_en.cfm [Accessed 11.12.2017]. 
et al., 2013; Kisiel and Idzkowska, 2014). Kulawik et al. (2013) identify two main agricultural tax regimes. Under the first one, farming activities are covered by the general taxation system. The second one provides separate regulations which may be either special preferential systems or limited preferences. Usually, tax preferences are used to make bookkeeping less burdensome, encourage saving and investment or promote insurance against catastrophic risks (Dziemianowicz and Budlewska, 2014). The national farming taxation system is extremely important as it affects the competitiveness of farms ${ }^{6}$ and other operators active in the agriculture sector (Wasilewski and Ganc, 2012). Also, it impacts the scale, structure, organization and lines of agricultural production while also having an effect on the use of productive inputs (Dziemianowicz, 2006; Forfa, 2011, after Hanusz, 1996).

The competitiveness of farms in member countries is also affected by the Common Agricultural Policy (CAP), and especially by the system of support through direct payments and subsidies. The importance of CAP for agricultural development, and especially for the profitability of farming, is particularly noticeable in countries who joined the Union in recent years. Financial support largely contributed to the growth of farmers' income (for a broader description, see Poczta, 2010) which, in turn, affects the amount of taxes paid. Therefore, a research on the level of, and changes in, farming taxation in EU member countries seems important.

\section{MATERIALS AND METHODS}

Because farm taxation is a complex aspect which may be described with a series of simple characteristics (sub-indicators), it was synthetically assessed with the classic TOPSIS approach, a pattern-based method for the creation of a synthetic indicator. The classic
TOPSIS approach is based on a concept introduced by Hwang and Yoon (1981). Unlike the Hellwig's (1968) method, it consists in calculating the (Euclidean or other) distance of objects considered not only from the pattern but also from the anti-pattern of development. The synthetic indicator of farm taxation in EU countries was created in five steps, as shown in Table 1.

The first step of this research consisted in selecting the simple characteristics. Based on substantive grounds, four simple characteristics were selected as the basis for the synthetic indicator of farm taxation: $\operatorname{taxes}^{7}$ per 1 ha of agricultural land utilized by the farm (EUR/ha) $\left(x_{1}\right)$; ratio of taxes to total labour inputs $\left(\mathrm{EUR} / \mathrm{AWU}^{8}\right)\left(x_{2}\right)$; ratio of taxes to total assets (EUR/EUR 1,000 worth of total assets) $\left(x_{3}\right)$; and share of taxes in the family farming income $(\%)\left(x_{4}\right)^{9}$. The set of simple characteristics established based on substantive grounds was subject to further statistical verification to determine their discriminatory capacity and information capacity. Because of the high variability of simple characteristics and their poor mutual correlation, all of them were used in further research.

The second step of the research procedure consisted in normalizing the values of simple characteristics with the use of the zero unitarization procedure (Table 1). The normalization procedure was performed for the aggregate of average figures from 2007-2009 and 2013-2015 (referred to as object-years) in order to ensure comparability of results in the years considered. Afterwards, in step 3, the values of model units (i.e. the development pattern and anti-pattern) were determined and used as a basis to calculate the Euclidean distances of each country considered from the development pattern and anti-pattern (step 4). Step 5 consisted in calculating the values of the synthetic characteristic based on the calculated distances of objects (countries) under consideration from the model

\footnotetext{
${ }^{6}$ By taking over part of the land rent. About theories of land rent see more Czyżewski (2009).

${ }^{7}$ The indicators listed above were based on FADN SE390, defined as 'Farm taxes and other dues (not including VAT and the personal taxes of the holder) and taxes and other charges on land and buildings. Subsidies on taxes are deducted' (IERiGŻ-PIB, 2016).

${ }^{8}$ The Annual Work Unit is equivalent to 2120 working hours per year (IERiGŻ-PIB, 2016).

${ }^{9}$ In research homogeneous feature weights were assumed.
} 
Proceedings of the 2018 International Scientific Conference 'Economic Sciences for Agribusiness and Rural Economy' No 1, Warsaw, 7-8 June 2018, pp. 327-334

Table 1. Steps of creating the synthetic indicator based on the classic TOPSIS approach

\begin{tabular}{|c|c|c|c|}
\hline \multicolumn{2}{|r|}{ Procedure step } & Step description & Calculation formulas \\
\hline Step 1 & $\begin{array}{l}\text { Selecting the simple } \\
\text { characteristics }\end{array}$ & $\begin{array}{l}\text { Selection and statistical } \\
\text { verification of simple } \\
\text { characteristics for this study } \\
\text { based on substantive grounds }\end{array}$ & - \\
\hline Step 2 & $\begin{array}{l}\text { Normalizing the values of } \\
\text { simple characteristics }\end{array}$ & $\begin{array}{l}\text { Using the zero unitarization } \\
\text { procedure }\end{array}$ & $\begin{array}{c}z_{i k}=\frac{x_{i k}-\min _{i}\left\{x_{i k}\right\}}{\max _{i}\left\{x_{i k}\right\}-\min _{i}\left\{x_{i k}\right\}} \\
\text { for variables with a stimulating effect } \\
z_{i k}=\frac{\max _{i}\left\{x_{i k}\right\}-x_{i k}}{\max _{i}\left\{x_{i k}\right\}-\min _{i}\left\{x_{i k}\right\}} \\
\text { for variables with an inhibiting effect }\end{array}$ \\
\hline Step 3 & $\begin{array}{l}\text { Calculating the coordinates } \\
\text { of model objects of the } \\
\text { pattern and anti-pattern }\end{array}$ & $\begin{array}{l}\text { The coordinates of the } \\
\text { development pattern }\left(A^{+}\right) \\
\text {and anti-pattern }\left(A^{-}\right) \text {are } \\
\text { calculated as the maximum } \\
\text { and minimum values, } \\
\text { respectively, of the set of } \\
\text { normalized values of simple } \\
\text { characteristics }\end{array}$ & \\
\hline Step 4 & $\begin{array}{l}\text { Calculating the distance } \\
\text { of each object from the } \\
\text { development pattern and } \\
\text { anti-pattern }\end{array}$ & $\begin{array}{l}\text { Calculating the Euclidean } \\
\text { distance of each multi- } \\
\text { characteristic object } i \text { from } \\
\text { the development pattern and } \\
\text { anti-pattern }\end{array}$ & $\begin{array}{l}d_{i}^{+}=\sqrt{\sum_{k=1}^{K}\left(z_{i k}-z_{k}^{+}\right)^{2}} \\
d_{i}^{-}=\sqrt{\sum_{k=1}^{K}\left(z_{i k}-z_{k}^{-}\right)^{2}}\end{array}$ \\
\hline Step 5 & $\begin{array}{l}\text { Calculating the value of the } \\
\text { synthetic indicator }\end{array}$ & $\begin{array}{l}\text { Based on Euclidean } \\
\text { distances from the } \\
\text { development pattern and } \\
\text { anti-pattern }\end{array}$ & $S_{i}=\frac{d_{i}^{-}}{d_{i}^{-}+d_{i}^{+}}$ \\
\hline
\end{tabular}

Source: own elaboration based on Wysocki (2010).

objects. This, in turn, was the basis for ranking the EU countries by level of farm taxation.

\section{RESULTS AND DISCUSSION}

As shown in Table 2, the highest levels of taxation per hectare of agricultural land were recorded in the Netherlands and Italy, ranging from ca EUR 62/ha (in Italy in 2007-2009) to slightly over EUR 124/ha (in the Netherlands in 2013-2015). This was several dozen times higher than the minimum level recorded in Swedish farms. Only four countries covered by this study (i.e. the Czech Republic, Lithuania, Slovakia and Denmark) reported a decrease in taxation per hectare of agricultural land over the study period. It was the contrary in all other countries; the highest increase was recorded in Finland (a growth rate of nearly $260 \%$ ). 
Proceedings of the 2018 International Scientific Conference 'Economic Sciences for Agribusiness and Rural Economy' No 1, Warsaw, 7-8 June 2018, pp. 327-334

Table 2. Farm taxation indicators for EU countries

\begin{tabular}{|c|c|c|c|c|c|c|c|c|c|c|c|c|}
\hline \multirow{2}{*}{ Specification } & \multicolumn{3}{|c|}{$\begin{array}{c}\text { Taxes per } 1 \text { ha } \\
\text { of agricultural land } \\
\text { (EUR/ha) }\end{array}$} & \multicolumn{3}{|c|}{$\begin{array}{c}\text { Taxes to total labour } \\
\text { inputs } \\
\text { (EUR/AWU) }\end{array}$} & \multicolumn{3}{|c|}{$\begin{array}{l}\text { Taxes per EUR 1,000 } \\
\text { worth of total assets } \\
\text { (EUR) }\end{array}$} & \multicolumn{3}{|c|}{$\begin{array}{l}\text { Share of taxes in family } \\
\text { farming incomes } \\
(\%)\end{array}$} \\
\hline & $\begin{array}{l}2007- \\
-2009\end{array}$ & $\begin{array}{l}2013- \\
-2015\end{array}$ & $\begin{array}{c}\text { change } \\
(\%)\end{array}$ & $\begin{array}{l}2007- \\
-2009\end{array}$ & $\begin{array}{l}2013- \\
-2015\end{array}$ & $\begin{array}{c}\text { change } \\
(\%)\end{array}$ & $\begin{array}{l}2007- \\
-2009\end{array}$ & $\begin{array}{l}2013- \\
-2015\end{array}$ & $\begin{array}{c}\text { change } \\
(\%)\end{array}$ & $\begin{array}{l}2007- \\
-2009\end{array}$ & $\begin{array}{l}2013- \\
-2015\end{array}$ & $\begin{array}{c}\text { change } \\
\text { (p.p.) }\end{array}$ \\
\hline Belgium & 41.7 & 47.0 & 112.6 & 927.4 & 1160.2 & 125.1 & 3.3 & 3.3 & 99.6 & 3.9 & 4.2 & 0.3 \\
\hline Bulgaria & 3.7 & 6.1 & 162.8 & 37.8 & 100.7 & 266.4 & 2.2 & 2.9 & 132.2 & 2.0 & 2.7 & 0.7 \\
\hline $\begin{array}{l}\text { Czech } \\
\text { Republic }\end{array}$ & 13.2 & 8.9 & 67.2 & 417.6 & 318.1 & 76.2 & 4.0 & 2.5 & 62.4 & 11.7 & 3.8 & -7.9 \\
\hline Denmark & 50.3 & 48.1 & 95.8 & 2645.2 & 2694.0 & 101.8 & 1.9 & 1.9 & 98.9 & -14.4 & 14.6 & 29.1 \\
\hline Germany & 24.9 & 33.9 & 136.4 & 908.6 & 1342.0 & 147.7 & 2.7 & 3.3 & 124.0 & 6.4 & 7.4 & 1.0 \\
\hline Greece & 8.9 & 16.3 & 182.8 & 54.2 & 150.2 & 277.2 & 0.8 & 1.4 & 175.4 & 0.5 & 1.5 & 1.0 \\
\hline Spain & 10.2 & 11.9 & 116.8 & 253.7 & 353.2 & 139.2 & 1.1 & 1.8 & 155.3 & 1.5 & 2.1 & 0.6 \\
\hline Estonia & 2.1 & 3.5 & 166.3 & 105.3 & 235.9 & 224.1 & 1.3 & 1.6 & 124.9 & 1.5 & 4.6 & 3.1 \\
\hline France & 23.8 & 25.6 & 107.3 & 1005.3 & 1080.5 & 107.5 & 5.2 & 5.1 & 97.5 & 6.3 & 6.5 & 0.2 \\
\hline Hungary & 10.0 & 13.9 & 138.6 & 298.9 & 427.2 & 142.9 & 3.6 & 3.8 & 103.8 & 4.4 & 3.6 & -0.8 \\
\hline Ireland & 3.3 & 5.0 & 153.4 & 130.1 & 209.3 & 160.9 & 0.2 & 0.3 & 161.2 & 0.8 & 1.0 & 0.2 \\
\hline Italy & 62.4 & 111.5 & 178.7 & 734.7 & 1635.5 & 222.6 & 3.0 & 4.6 & 152.9 & 4.1 & 7.3 & 3.1 \\
\hline Lithuania & 3.5 & 2.5 & 73.0 & 83.5 & 68.8 & 82.5 & 1.6 & 1.0 & 63.9 & 1.0 & 1.0 & 0.0 \\
\hline Luxembourg & 15.2 & 15.9 & 104.1 & 706.6 & 728.9 & 103.2 & 1.2 & 1.1 & 91.3 & 3.0 & 2.4 & -0.6 \\
\hline Latvia & 4.4 & 8.3 & 190.0 & 131.4 & 271.4 & 206.5 & 2.8 & 3.8 & 136.3 & 2.6 & 5.0 & 2.4 \\
\hline Netherlands & 94.0 & 124.2 & 132.1 & 1269.4 & 1652.1 & 130.1 & 1.8 & 1.9 & 103.6 & 10.0 & 7.3 & -2.7 \\
\hline Austria & 27.2 & 36.3 & 133.6 & 572.2 & 714.4 & 124.8 & 2.1 & 2.5 & 119.5 & 3.1 & 4.8 & 1.7 \\
\hline Poland & 16.7 & 20.9 & 125.1 & 179.0 & 231.7 & 129.4 & 2.9 & 2.3 & 80.3 & 3.8 & 4.4 & 0.6 \\
\hline Portugal & 4.8 & 8.1 & 170.0 & 74.5 & 132.9 & 178.3 & 1.3 & 2.0 & 153.2 & 1.1 & 1.4 & 0.3 \\
\hline Romania & 17.6 & 18.3 & 104.4 & 86.5 & 147.9 & 171.0 & 4.4 & 4.7 & 106.4 & 3.8 & 3.5 & -0.3 \\
\hline Finland & 4.9 & 12.6 & 258.7 & 186.8 & 593.9 & 318.0 & 0.7 & 1.6 & 228.0 & 1.2 & 4.1 & 2.9 \\
\hline Sweden & 1.3 & 1.7 & 134.4 & 80.6 & 116.2 & 144.0 & 0.2 & 0.2 & 93.4 & 0.6 & 1.1 & 0.5 \\
\hline Slovakia & 15.5 & 12.5 & 80.7 & 517.8 & 517.9 & 100.0 & 9.1 & 6.2 & 68.1 & -32.0 & 37.7 & 69.7 \\
\hline Slovenia & 3.5 & 4.7 & 132.3 & 22.3 & 35.0 & 157.0 & 0.2 & 0.2 & 119.0 & 0.6 & 1.0 & 0.4 \\
\hline $\begin{array}{l}\text { United } \\
\text { Kingdom }\end{array}$ & 5.0 & 6.0 & 119.2 & 361.6 & 448.0 & 123.9 & 0.6 & 0.5 & 82.4 & 1.7 & 2.3 & 0.6 \\
\hline
\end{tabular}

* This study does not include Malta and Cyprus (due to marginal importance of local agriculture) and Croatia (due to lack of 2007-2009 statistical data).

Source: own study based on FADN data. 
Proceedings of the 2018 International Scientific Conference 'Economic Sciences for Agribusiness and Rural Economy' No 1, Warsaw, 7-8 June 2018, pp. 327-334

The changes were even more pronounced for the amount of taxes per FTE. In 2013-2015, only Czech and Lithuanian farms recorded a lower level of employment taxes compared to 2007-2009 (by ca 17 and $24 \%$, respectively). It was the contrary in all other countries; the highest growth rates were experienced in Finland, Greece and Bulgaria (Table 2).

The ratio of taxes to EUR 1,000 worth of total assets did not change that much over the period considered. In both time intervals, the lowest levels were reported by Slovenian, Swedish and Irish farms whereas Slovakian farms reached the highest ratios. As regards the share of taxes in the family farming income, the least favourable indicators were reported by Slovakian and Danish farms (37.7 and 14.6\%, respectively, in 2013-2015). In the study period, the greatest improvement in that area was observed in Czech farms (a decline by nearly 8 p.p.) - Table 2

As shown by this study, in 2013-2015, the level of farm taxation in EU countries was higher than in 2007-2009 (Table 3). In 2007-2009, the synthetic indicator of EU farm taxation ranged from 0.011 (in Slovenia) to 0.517 (in Denmark). In the 2013-2015 period, the range of variation was broader, with the values spanning from 0.017 in Slovenia to 0.650 in Italy. The study also evidenced the persistently high differences in farm taxation levels between European countries. This is reflected by the coefficient of variation for the synthetic indicator which consistently exceeds $70 \%$ in both periods under consideration.

The country ranking (Table 3 ) suggests that Danish and Dutch farms continue to pay the highest taxes. However, this is no longer the case for Slovakia, ranked third and seventh in 2007-2009 and 2013-2015, respectively. Italian farms became the leaders as they moved up from the fifth rank to the first. A more stable situation was ob-
Table 3. EU countries ranked by level of farm taxation in 2007-2009 and 2013-2015

\begin{tabular}{|l|c|c|c|c|c|}
\hline \multirow{2}{*}{ Specification } & \multicolumn{2}{|c|}{$2007-2009$} & \multicolumn{2}{|c|}{$2013-2015$} & \multirow{2}{*}{$\begin{array}{c}\text { Difference } \\
\text { in ranks }\end{array}$} \\
\cline { 2 - 6 } & $\begin{array}{c}\text { synthetic } \\
\text { indicator }\end{array}$ & rank & $\begin{array}{c}\text { synthetic } \\
\text { indicator }\end{array}$ & rank & -2 \\
\hline Denmark (DAN) & 0.517 & 1 & 0.517 & 3 & 0 \\
\hline Netherlands (NED) & 0.475 & 2 & 0.570 & 2 & -4 \\
\hline Slovakia (SVK) & 0.460 & 3 & 0.359 & 7 & 0 \\
\hline France (FRA) & 0.384 & 4 & 0.391 & 4 & 4 \\
\hline Italy (ITA) & 0.368 & 5 & 0.650 & 1 & 1 \\
\hline Belgium (BEL) & 0.341 & 6 & 0.384 & 5 & 1 \\
\hline Germany (DEU) & 0.273 & 7 & 0.376 & 6 & 0 \\
\hline Romania (ROU) & 0.261 & 8 & 0.278 & 8 & -6 \\
\hline Czech Republic (CZE) & 0.257 & 9 & 0.166 & 15 & 0 \\
\hline Hungary (HUN) & 0.224 & 10 & 0.246 & 10 & 0 \\
\hline Austria (OST) & 0.210 & 11 & 0.268 & 9 & 2 \\
\hline Poland (POL) & 0.187 & 12 & 0.170 & 13 & -1 \\
\hline Luxembourg (LUX) & 0.172 & 13 & 0.175 & 12 & 1 \\
\hline Latvia (LVA) & 0.162 & 14 & 0.227 & 11 & 3 \\
\hline Bulgaria (BGR) & 0.125 & 15 & 0.168 & 14 & 1 \\
\hline Lithuania (LTU) & 0.094 & 16 & 0.057 & 22 & -6 \\
\hline Spain (ESP) & 0.091 & 17 & 0.135 & 17 & 0 \\
\hline United Kingdom (UKI) & 0.080 & 18 & 0.095 & 21 & -3 \\
\hline Portugal (POR) & 0.074 & 19 & 0.120 & 18 & 1 \\
\hline Estonia (EST) & 0.074 & 20 & 0.103 & 20 & 0 \\
\hline Greece (ELL) & 0.054 & 21 & 0.108 & 19 & 2 \\
\hline Finland (SUO) & 0.053 & 22 & 0.162 & 16 & 6 \\
\hline Ireland (IRE) & 0.025 & 23 & 0.044 & 23 & 0 \\
\hline Sweden (SVE) & 0.013 & 24 & 0.020 & 24 & 0 \\
\hline Slovenia (SVN) & 25 & 0.017 & 25 & 0 \\
\hline Median & $\times$ & 0.170 & $\times$ & $\times$ \\
\hline Coefficient of variation & 76.7 & & & -6 \\
\hline
\end{tabular}

Countries arranged linearly by the value of the synthetic indicator in 2007-2009.

Source: own study based on FADN data. 
Proceedings of the 2018 International Scientific Conference 'Economic Sciences for Agribusiness and Rural Economy' No 1, Warsaw, 7-8 June 2018, pp. 327-334

served in Slovenia, Sweden and Ireland: the countries with the lowest levels of farm taxation in both periods covered by this study. The most unfavourable changes in taxation levels could be observed in Finland (the difference in ranks was 6). In was the oppo- site for Czech and Lithuanian farms who dropped in the ranking from tenth to fifteenth and from sixteenth to twenty second, respectively.

Figures 1 and 2 show the levels of farm taxation in EU countries and, respectively, the farms' economic

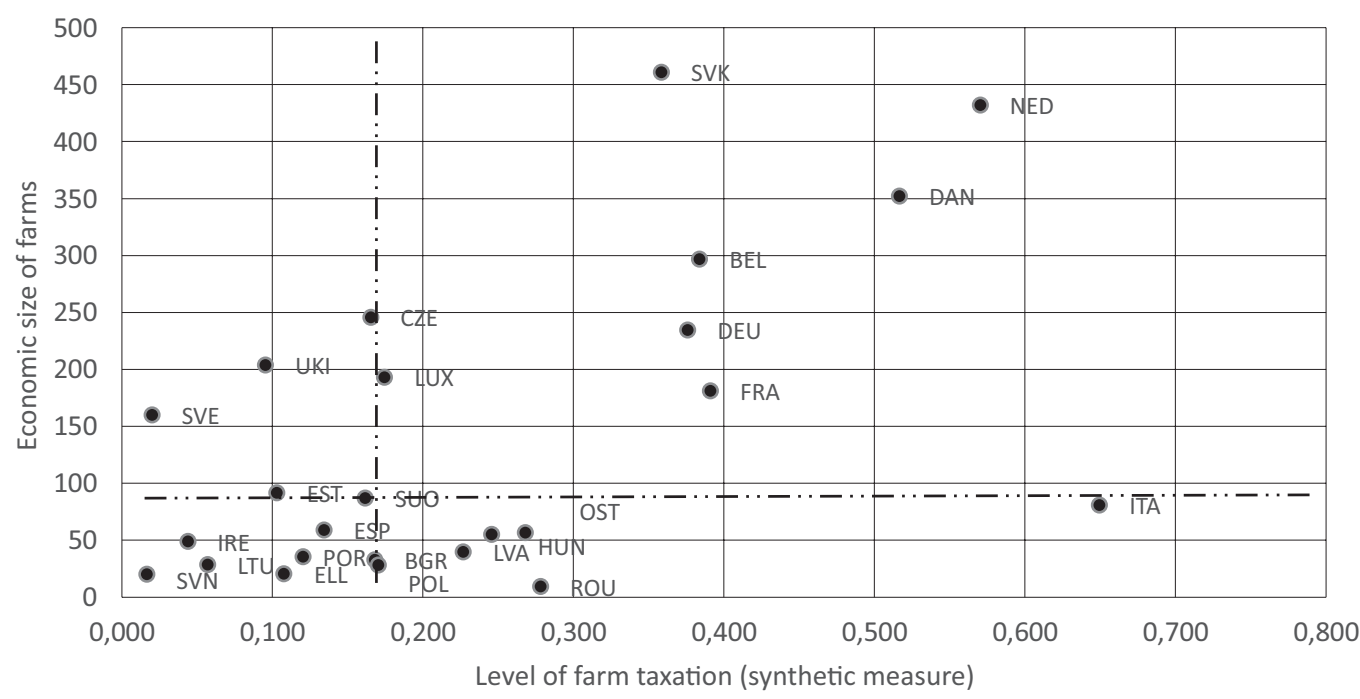

Figure 1. Correlation graph for the taxation level and economic size of farms in European Union countries (average values in 2013-2015; the Pearson linear correlation coefficient is 0.56 ; the vertical and horizontal lines represent the average values of characteristics under consideration)

Source: own study based on FADN data.

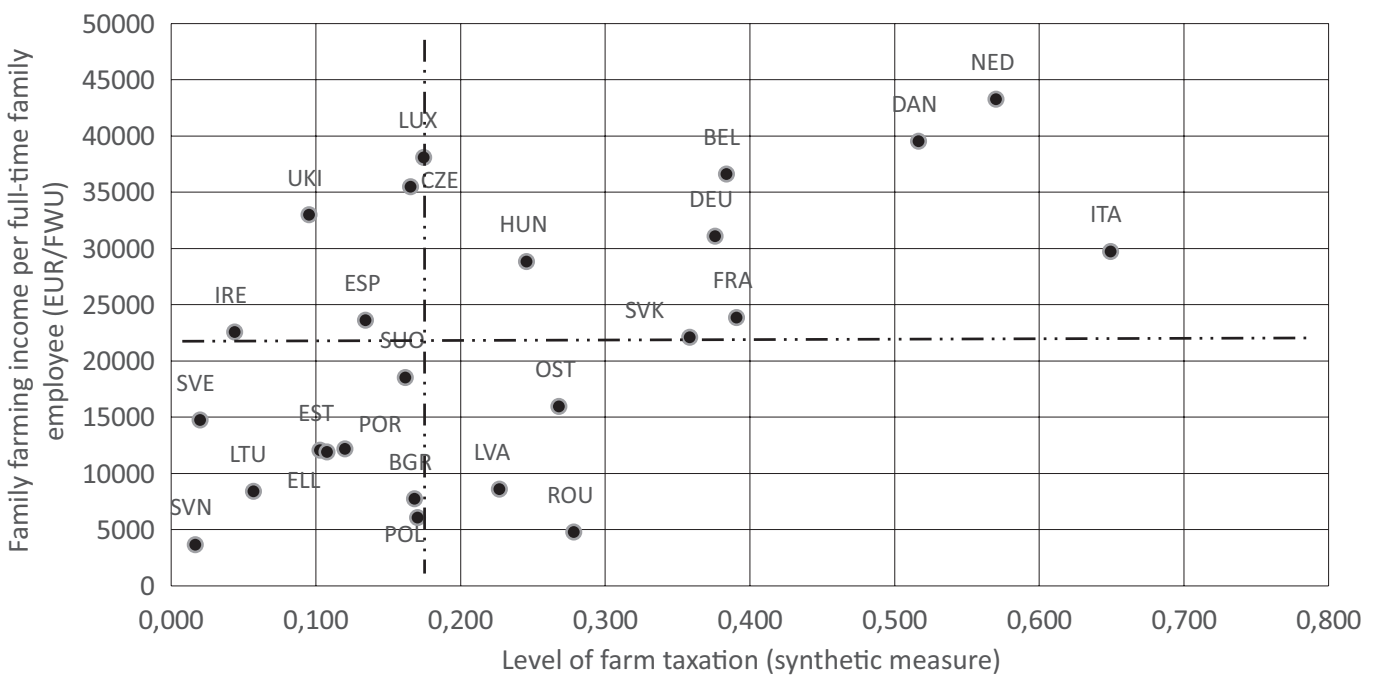

Figure 2. Correlation graph for the taxation level and family farming income per full-time family employee (EUR/ FWU) in European Union countries (average values in 2013-2015; the Pearson linear correlation coefficient is 0.57 ; the vertical and horizontal lines represent the average values of characteristics under consideration) Source: own study based on FADN data. 
size and own labour profitability in 2013-2015. Based on Figure 1 data, it may be concluded that farms dealing with higher taxation levels were usually economically stronger. This is especially true for Dutch, Danish and Slovakian farms. However, that pattern was not followed by Italian farms who, tough small in economic terms, experienced the highest taxation levels in 2013-2015.

A certain relationship could also be traced between the level of farm taxation and the farms' own labour productivity (Fig. 2). With some exceptions, the farms demonstrating a high value of the synthetic indicator were also characterized by high levels of family farming income per full-time family employee (especially in the Netherlands and Denmark).

\section{CONCLUSIONS}

Based on this study, the level of farm taxation was confirmed to differ significantly across EU countries. In the study period, the highest levels of taxation were imposed on Danish, Dutch, Italian, French, Slovakian and Belgian farms. In turn, Slovenian, Swedish and Irish farms were ranked at the bottom. It may be concluded that farms charged with higher and lower amounts of taxes are generally those characterized by a high and low production intensity, respectively. High and low levels of farm taxation were usually found in countries with a relatively great or small importance, respectively, of the agriculture for the national economy. Note also that in 2007-2015, most EU countries experienced an increase in farm taxation levels. Countries where taxes play the least important role remained stable in the ranking. In turn, the group of top-ranked countries has considerably changed, with Italy moving four ranks up to become the leader. Conversely, Slovenia lost its high taxation status. The most favourable and the most unfavourable changes in taxation levels were observed in the Czech Republic and Lithuania, respectively (each of these countries moved six ranks up/down). Higher taxation levels were usually found to be accompanied by a higher productivity of non-salaried labour and by a greater economic strength of farms.

\section{Acknowledgements}

The project was financed from resources of the National Center for Science, allocated pursuant to decision DEC-2012/05/B/HS4/04134.

\section{REFERENCES}

1. Czyżewski, B. (2009). Współczesne teorie renty gruntowej, ich geneza i znaczenie dla Wspólnej Polityki Rolnej w UE [Contemporary theories of land rent, its origins and application to Common Agricultural Policy in the EU]. Polityki Europejskie, Finanse i Marketing, 2 (Vol. 2), pp. 39-55.

2. Dziemianowicz, R. (2006). Podatki i ich wpływ na konkurencyjność gospodarstw rolnych. Agrobiznes $2006-$ konkurencja w agrobiznesie - jej uwarunkowania i następstwa [Taxes and their impact on competitiveness of farm businesses. Agribusiness 2006: the conditions and consequences of agribusiness competition]. Zeszyty Naukowe Uniwersytetu Ekomonicznego we Wrocławiu, 1118, pp. 216-222.

3. Dziemianowicz, R., Budlewska R. (2014). Preferencje podatkowe jako instrument polityki rolnej - na przykładzie wybranych państw Unii Europejskiej [Tax preferences as an agricultural policy instrument, illustrated by the examples of selected European Union countries]. Zeszyty Naukowe SGGW w Warszawie. Problemy Rolnictwa Światowego, 14 (29), 2, pp. 43-58.

4. Forfa, M. (2011). Obciążenie fiskalne gospodarstw rolniczych w zależności od wielkości ekonomicznej oraz typu rolniczego [Farm taxation in function of economic size and agricultural type]. Zeszyty Naukowe SGGW w Warszawie. Ekonomika i Organizacja Gospodarki Żywnościowej, 92, pp. 89-101.

5. Golasa, P. (2015). Obciążenia podatkowe rodzinnych gospodarstw rolnych [Family farm taxation]. In: Podstawka, M. (ed.) Ekonomiczne i prawne mechanizmy wspierania i ochrony rolnictwa rodzinnego [Economic and legal mechanisms to support and protect family farming]. Warszawa, pp. 62-77.

6. Hanusz, A. (1996). Polityka podatkowa w zakresie różnicowania obciążeń dochodów rolniczych [Provisions of fiscal policy regarding differentiation of farm taxation]. Wydawnictwo Uniwersytetu Marii Curie-Skłodowskiej w Lublinie, Lublin.

7. IERiGŻ-PIB (2016). Wyniki standardowe 2015 uzyskane przez gospodarstwa rolne uczestniczące w Polskim FADN. Część I. Wyniki standardowe [Standard results 2015 obtained by agricultural holdings participating in the Polish FADN. Part I. Standard results]. Warszawa. 
8. Hellwig, Z. (1968). Zastosowanie metody taksonomicznej do typologicznego podziału krajów ze względu na poziom ich rozwoju oraz zasoby i strukturę wykwalifikowanych kadr [Using the taxonomic method for a typological classification of countries by development levels and by resources and structure of skilled labour]. Przegląd Statystyczny, 4, pp. 307-326.

9. Hwang, C.L., Yoon, K. (1981). Multiple attribute decision-making: Methods and applications. Springer, Berlin.

10. Kisiel, R., Idzkowiak, K. (2014). System opodatkowania rolnictwa w Polsce oraz w wybranych krajach Unii Europejskiej [Farm taxation systems in Poland and in selected European Union countries]. Polityki Europejskie, Finanse i Marketing, 12 (61), pp. 64-78.

11. Kulawik, J., Lelong, P.Y., Pawłowska-Tyszko, J., Soliwoda, M. (2013). Systemy podatkowe w krajach Unii Europejskiej [Fiscal systems in European Union countries]. Instytut Ekonomiki Rolnictwa i Gospodarki Żywnościowej - Państwowy Instytut Badawczy, Warszawa.
12. Poczta, W. (2010). Sytuacja dochodowa gospodarstw rolnych w Polsce po akcesji do UE i jej determinanty jako przesłanka rozwoju rolnictwa [Income situation of Polish farms following the accession to the EU and its determinants as a condition for agricultural development]. Annuals of Agricultural Sciences, G, 97 (3), pp. 205-217.

13. Wasilewski, M., Ganc, M. (2012). Funkcjonowanie systemu podatkowego $\mathrm{w}$ rolnictwie oraz propozycje zmian w opinii rolnikow indywidualnych [Functioning of the farm taxation system; individual farmers' feedback on changes proposed]. Finanse, Rynki Finansowe, Ubezpieczenia, 50, p. 725-733.

14. Wysocki, F. (2010). Metody taksonomiczne w rozpoznawaniu typów ekonomicznych rolnictwa i obszarów wiejskich [Taxonomic methods in the identification of economic types of agriculture and rural areas]. Wydawnictwo Uniwersytetu Przyrodniczego w Poznaniu, Poznań. 